\title{
Badania ograniczenia pienienia cieczy wodorozcieńczalnych
}

\begin{abstract}
W pracy badano wodorozcieńczalny koncentrat półsyntetyczny oraz wodorozcieńczalny koncentrat wysokoolejowy cieczy chłodząco-smarujących z pięcioma środkami przeciwpiennymi o różnym charakterze chemicznym. W koncentratach zastosowano, zalecane przez producentów, minimalne i maksymalne stężenia środków przeciwpiennych. Z koncentratów sporządzono 5-procentową $(\mathrm{m} / \mathrm{m})$ emulsje w wodzie o twardościach: 0 , 15 i $30^{\circ} \mathrm{n}$. W badaniach porównawczych zastosowano procedurę INiG - PiB oznaczania skłonności do pienienia emulsji cieczy wodorozcieńczalnych. Dodatkowo zbadano ich napięcie powierzchniowe, a także $\mathrm{pH}$.
\end{abstract}

Słowa kluczowe: pienienie, środek przeciwpienny, wodorozcieńczalne ciecze do obróbki metali.

\section{Foam reduction tests for soluble metalworking fluids}

Concentrates of a semi-synthetic watermiscible coolant and a water soluble metalworking fluid with five different defoamers were investigated. Concentrates with water, recommended by manufacturers, minimum and maximum concentrations of defoamers were used. Concentrates of $5 \%(\mathrm{~m} / \mathrm{m})$ emulsions in water of hardness: 0,15 and $30^{\circ} \mathrm{n}$. In comparative studies, the author's INiG - PiB procedure was used to determine the foaming tendency of the watermiscible metalworking fluids. Additionally, the surface tension and $\mathrm{pH}$ were also investigated.

Key words: foaming, defoamer, antifoamer, soluble metalworking fluid.

\section{Wstęp}

Wodorozcieńczalne ciecze wykorzystywane w przemyśle to przede wszystkim ciecze chłodząco-smarujące do powierzchniowej obróbki metali. Wodorozcieńczalne ciecze chłodząco-smarujące (w postaci chłodziw emulsyjnych) stosuje się w procesach obróbki skrawaniem, tj. w obróbce wiórowej i ściernej: stali, żeliwa, metali nieżelaznych i ich stopów, gdzie wymagane jest szybkie odprowadzenie ciepła, właściwe smarowanie i dobre właściwości myjące. Gotową ciecz chłodząco-smarującą (emulsję) otrzymuje się poprzez wymieszanie koncentratu $\mathrm{z}$ wodą, najczęściej z wykorzystaniem dostępnego ujęcia wody. Zalecane stężenie koncentratu w wodzie zależy od rodzaju obróbki oraz od charakteru chemicznego stosowanej cieczy chłodząco-smarującej (emulsji) [18, 21]. Koncentrat to układ złożony z olejów (mineralnych, półsyntetycznych, syntetycznych), emulgatora oraz różnych dodatków (antyutleniaczy, inhibitorów korozji, dodatków przeciwzużyciowych EP, przeciwpiennych i biocydów), zależnie od przeznaczenia emulsji $[18,19]$. Dzięki stosowaniu w ich skła- dzie emulgatorów możliwe jest wytworzenie stabilnych emulsji chłodziw otrzymywanych z koncentratów, zawierających oleje oraz inne niemieszające się z wodą składniki. W zależności od proporcji składników wchodzących w skład koncentratów wodorozcieńczalnych cieczy chłodząco-smarujących, a szczególnie zawartego w nich oleju, stosowany jest często podział na ciecze [7, 16-19]:

- konwencjonalne (wysokoolejowe), w których głównym (pod względem udziału) składnikiem kompozycji jest olej mineralny $-\mathrm{z}$ wodą tworzą one mleczne ciecze makroemulsyjne,

- półsyntetyczne, w których udział środków powierzchniowo czynnych i dodatków jest dominujący, przewyższający udział olejów mineralnych - tworzą one $\mathrm{z}$ wodą ciecze półprzeźroczyste lub transparentne,

- syntetyczne, tworzące z wodą roztwory lub ciecze mikroemulsyjne, w których stosowane są glikole, poliglikole, lekkie oleje syntetyczne lub estrowe. 
Wykorzystywanie chłodziw zamiast olejów obróbczych w znacznym stopniu obniża koszty eksploatacyjne z uwagi na wysokie rozcieńczanie wodą, brak zaolejenia wiórów, możliwość utrzymania czystości hali produkcyjnej oraz zmniejszenie emisji mgły olejowej. Wiąże się ono jednak z koniecznością prowadzenia częstej kontroli i pielęgnacji emulsji w trakcie eksploatacji. Bardzo ważnym kryterium jest dobór środka do rodzaju obrabianego materiału. W zależności od składu i twardości wody wykorzystanej do sporządzenia emulsji ciecze chłodząco-smarujące wykazują różne skłonności do pienienia. Tworzenie piany jest zjawiskiem niekorzystnym, ponieważ zakłóca pracę urządzeń i może podczas eksploatacji maszyn powodować następujące skutki:

- redukcję efektywności emulsji, czyli niedostateczne smarowanie, w rezultacie zbyt małej ilości środka smarowego doprowadzanego do skojarzenia trącego,

- niedostateczne odprowadzanie ciepła, a tym samym problemy z zapewnieniem odpowiedniej jakości obrabianych detali,

- wypływanie cieczy eksploatacyjnych ze zbiorników maszyny, np. poprzez otwory odpowietrzające,

- zwiększenie skłonności do występowania zjawiska kawitacji (gwałtownej przemiany fazowej z fazy ciekłej w fazę gazową pod wpływem zmniejszenia ciśnienia), a tym samym redukcję wydajności pomp,

- redukcję pojemności pomp i zbiorników,

- wzrost intensywności namnażania bakterii,

- flotację zanieczyszczeń, tworzenie depozytów zanieczyszczeń,

- częste przestoje w produkcji spowodowane czyszczeniem zbiorników,

- problemy z drenażem sit i filtrów,

- zwiększenie kosztów produkcji związanych z częstszą wymianą eksploatowanej emulsji oraz eliminacją wybrakowanych produktów.

Aby uniknąć powyższych problemów, wodorozcieńczalne ciecze chłodząco-smarujące powinny charakteryzować się brakiem lub jak najmniejszą skłonnością do pienienia, co można uzyskać poprzez dobór odpowiedniego środka przeciwpiennego.

Pierwotnie jako środki przeciwpienne (np. w płynach hydraulicznych) stosowano oleje silikonowe ze względu na ich niewielkie napięcie powierzchniowe. Wadą tej metody było częściowe odparowywanie tych olejów. Obecnie problem ten został rozwiązany poprzez wykorzystanie organomodyfikowanych siloksanów.

Większość nowoczesnych i efektywnych środków przeciwpiennych jest wieloskładnikowa. Zawierają one w swoim składzie mieszaninę olejów silikonowych, surfaktantów silikonowych lub silikażeli z możliwie dwoma lub więcej typami rozproszonych hydrofobowych agregatów (wielkości około $1 \mu \mathrm{m}$, gęstości względnej 1,0 $\div 1,3$ i szorstkim kształcie fraktalnym).
Takie mieszaniny wykazują dużą skuteczność już przy niewielkim stężeniu $(10 \div 1000 \mathrm{ppm})$. Te wieloskładnikowe środki zbudowane są ze stałego ,aktywatora”, w postaci hydrofobizowanej krzemionki lub szkła, oraz ciekłego „nośnika”, w postaci węglowodoru, polidimetylosiloksanu (PDMS) lub oleju $[2-4,9,13-15,20]$.

Jednozadaniowe środki przeciwpienne stosuje się przeciwko pianom wodnym w wielu różnych formach: w postaci rozpuszczalnych lub nierozpuszczalnych cieczy, olejów, żeli, stałych hydrofobowych cząstek, emulsji i mikroemulsji. Są one mniej skuteczne, ale zdecydowanie tańsze. Wśród typowych związków chemicznych, jakie wchodzą w ich skład, można wymienić: fosforan tributylu (TBP), polidimetylosiloksan (PDMS), płyny silikonowe, aminy alkilowe, amidy, tioetery, oleje mineralne i roślinne, woski, estry kwasów tłuszczowych, alkohole (np. oktanol), kwasy tłuszczowe oraz ich pochodne (olej talowy, stearynian glinu oraz wapniowe, glinowe, cynkowe sole kwasów tłuszczowych), a także wiele różnych typów cząstek stałych [9-15]. Do środków tych można również zaliczyć estry glicerylu oraz syntetyczne estry alkoholi wielowodorotlenowych. Obecnie trwają również badania nad zastosowaniem w środkach przeciwpiennych cieczy jonowych, np. opartych na fosfonianach [1].

Do grupy związków przeciwpiennych należą także niejonowe etoksylowane i propoksylowane kopolimery blokowe typu PEO-PPO-PEO lub PPO-PEO-PPO i poloksamery, nazywane cloud point antifoamers: copolymers [9,13, 14]. Polarność tego typu kopolimerów zależy od stosunku komponentów hydrofilowych (politlenku etylenu, PEO) do hydrofobowych (politlenku propylenu, PPO). Cloud point antifoamers dość dobrze rozpuszczają się $\mathrm{w}$ wodzie $\mathrm{w}$ niskich temperaturach, natomiast tylko częściowo w wysokich temperaturach, a powyżej temperatury mętnienia (ang. cloud point) roztwór środka przeciwpiennego ulega zmianie fazowej, tworząc dwa sprzężone roztwory (dwie fazy): jeden bardziej rozcieńczony, a drugi stężony. W temperaturze mętnienia wydzielające się krople kopolimerów powodują, że roztwory (fazy) stają się mętne. Temperatura ta może być modyfikowana poprzez zmianę stosunku PEO/PPO. Przeważnie tego typu związki są dodawane do pieniących roztworów surfaktantów na bazie wody w celu uzyskania efektu przeciwpiennego w temperaturze zbliżonej do temperatury mętnienia. Natomiast w niektórych przypadkach, ze względu na mieszalność z innymi surfaktantami, temperatura mętnienia może wzrosnąć lub nawet zostać całkowicie wyeliminowana.

Jako że istnieje bardzo wiele różnych związków chemicznych charakteryzujących się właściwościami przeciwpiennymi, jest wiele alternatywnych mechanizmów wyjaśniających sposób ich działania [3, 5, 6, 14]. Niemniej jednak główną funkcją środków zapobiegających pienieniu jest zastąpienie lub zredukowanie ilości generującego pianę środka 
powierzchniowo czynnego obecnego na powierzchni zetknięcia się dwóch faz, co ostatecznie prowadzi do mniejszej stabilności filmu piany. Substancja chemiczna zapobiegająca pienieniu musi być przy tym nierozpuszczalna w ośrodku powodującym pienienie i równocześnie odporna na rozkład chemiczny $[8,9,14]$. Zasadnicze wymaganie, jakie muszą spełniać środki przeciwpienne, polega na ich zdolności przedostawa- nia się na granicę faz powietrze-ciecz, dlatego też muszą posiadać odpowiednio niskie napięcie powierzchniowe (mniejsze niż napięcie powierzchniowe cieczy, do której są dodawane) [14]. W przypadku pian wodnych stosunkowo łatwo jest sprostać temu wymaganiu, natomiast dla pian niewodnych można osiągnąć taki efekt tylko poprzez zastosowanie specyficznych surfaktantów (opartych na olejach silikonowych).

\section{Próbki}

Do badań wytypowano dwa koncentraty bazowych cieczy chłodząco-smarujących:

- koncentrat 1 - cieczy półsyntetycznej,

- koncentrat 2 - cieczy wysokoolejowej.

Oba koncentraty powstały z wykorzystaniem komercyjnych składników. $Z$ tak otrzymanych bazowych koncentra- tów przygotowano próbki koncentratów, dodając do nich środki przeciwpienne o różnym charakterze chemicznym, w minimalnych i maksymalnych zalecanych przez producentów stężeniach. Szczegółową charakterystykę tych środków przeciwpiennych, a także zalecane minimalne i maksymalne stężenie przedstawiono w tablicy 1. Dane te uzyskano

Tablica 1. Charakterystyka dodatków przeciwpiennych

\begin{tabular}{|c|c|c|}
\hline \multirow{5}{*}{ Dodatek P1 } & Charakter chemiczny & mieszanina trójwymiarowego siloksanu z polioksyalkilanem \\
\hline & Rekomendowane dozowanie $[\%(\mathrm{~m} / \mathrm{m})]$ & $0,05 \div 0,1$ \\
\hline & Wygląd w temperaturze $20^{\circ} \mathrm{C}$ & nieprzeźroczysta ciecz barwy białej do jasnożółtej \\
\hline & Lepkość dynamiczna w temperaturze $20^{\circ} \mathrm{C}[\mathrm{mPa} \cdot \mathrm{s}]$ & 1350 \\
\hline & Gęstość w temperaturze $20^{\circ} \mathrm{C}[\mathrm{g} / \mathrm{ml}]$ & 0,838 \\
\hline \multirow{5}{*}{ Dodatek P2 } & Charakter chemiczny & mieszanina trójwymiarowego siloksanu z wodą \\
\hline & Rekomendowane dozowanie $[\%(\mathrm{~m} / \mathrm{m})]$ & $0,1 \div 0,5$ \\
\hline & Wygląd w temperaturze $20^{\circ} \mathrm{C}$ & nieprzeźroczysta ciecz barwy białej \\
\hline & Lepkość dynamiczna w temperaturze $20^{\circ} \mathrm{C}[\mathrm{mPa} \cdot \mathrm{s}]$ & 1250 \\
\hline & Gęstość w temperaturze $20^{\circ} \mathrm{C}[\mathrm{g} / \mathrm{ml}]$ & 0,827 \\
\hline \multirow{6}{*}{ Dodatek P3 } & Charakter chemiczny & $\begin{array}{c}\text { mieszanina kopolimeru blokowego ( } \mathrm{z} \text { dwiema grupami glikolu } \\
\text { polietylenowego przyłączonymi do centralnej grupy glikolu } \\
\text { propylenowego) z wodą }\end{array}$ \\
\hline & Rekomendowane dozowanie $[\%(\mathrm{~m} / \mathrm{m})]$ & $0,1 \div 0,5$ \\
\hline & Wygląd w temperaturze $20^{\circ} \mathrm{C}$ & bezbarwna ciecz \\
\hline & Lepkość dynamiczna w temperaturze $20^{\circ} \mathrm{C}[\mathrm{mPa} \cdot \mathrm{s}]$ & 350 \\
\hline & Gęstość w temperaturze $20^{\circ} \mathrm{C}[\mathrm{g} / \mathrm{ml}]$ & 1,02 \\
\hline & Temperatura mętnienia $\left(1 \% \mathrm{w} \mathrm{H} \mathrm{H}_{2} \mathrm{O}_{\text {destyl. }}\right)\left[{ }^{\circ} \mathrm{C}\right]$ & 23 \\
\hline \multirow{5}{*}{ Dodatek P4 } & Charakter chemiczny & mieszanina polidimetylosiloksanu z wodą \\
\hline & Rekomendowane dozowanie $[\%(\mathrm{~m} / \mathrm{m})]$ & $0,1 \div 0,5$ \\
\hline & Wygląd w temperaturze $20^{\circ} \mathrm{C}$ & nieprzeźroczysta ciecz barwy białej \\
\hline & Lepkość dynamiczna w temperaturze $20^{\circ} \mathrm{C}[\mathrm{mPa} \cdot \mathrm{s}]$ & 660 \\
\hline & Gęstość w temperaturze $20^{\circ} \mathrm{C}[\mathrm{g} / \mathrm{ml}]$ & 1,10 \\
\hline \multirow{6}{*}{ Dodatek P5 } & Charakter chemiczny & $\begin{array}{l}\text { mieszanina polidimetylosiloksanów, cyklosiloksanów } \\
\text { i krzemionki z wodą }\end{array}$ \\
\hline & Zawartość części stałych [\%] & $10 \div 14$ \\
\hline & Rekomendowane dozowanie $[\%(\mathrm{~m} / \mathrm{m})]$ & $0,05 \div 0,1$ \\
\hline & Wygląd w temperaturze $20^{\circ} \mathrm{C}$ & nieprzeźroczysta ciecz barwy białej \\
\hline & Lepkość dynamiczna w temperaturze $20^{\circ} \mathrm{C}[\mathrm{mPa} \cdot \mathrm{s}]$ & 500 \\
\hline & Gęstość w temperaturze $20^{\circ} \mathrm{C}[\mathrm{g} / \mathrm{ml}]$ & 0,98 \\
\hline
\end{tabular}


od producentów tych dodatków na podstawie świadectw jakości, informacji technicznych (TDS) oraz kart charakterystyki (MSDS).

Następnie przygotowano próbki cieczy chłodząco-smarujących, emulsje typu W/O (woda w oleju). Te emulsje, o stę- żeniu 5\% $(\mathrm{m} / \mathrm{m})$, sporządzono na wodach o trzech różnych twardościach: 0,15 i $30^{\circ} \mathrm{n}$. Wodę destylowaną $\left(0^{\circ} \mathrm{n}\right)$ gotowano przez około 30 minut w celu usunięcia kwasu węglowego, natomiast wodę o twardościach $15^{\circ} \mathrm{n}$ i $30^{\circ} \mathrm{n}$ przygotowano zgodnie z normą PN-M-55789 [24].

\section{Metodyka badań}

W kolejnym etapie prac emulsje te, czyli gotowe do użycia ciecze chłodząco-smarujące, poddano badaniom, oznaczając:

- skłonność do pienienia - metodą INiG - PIB,

- napięcie powierzchniowe - według PN-C-04809 [22],

- $\mathrm{pH}$ - według PN-C-04963 [23].

Wyniki tych badań przedstawiono w tablicach 2-5.

\section{Skłonność do pienienia emulsji cieczy wodorozcieńczalnych - metoda INiG - PIB}

Skłonność do pienienia cieczy określa się za pomocą dwóch parametrów: ilości piany powstałej podczas napowietrzania oraz szybkości gaśnięcia piany.

Zasada metody polega na przedmuchiwaniu powietrza przez badaną próbkę płynu ze stałą prędkością, w określonej temperaturze i określonym czasie, a następnie na pomiarze objętości powstałej piany i pomiarze czasu jej zaniku. Objętość piany obliczono z różnicy zanotowanych poziomów piany i płynu, a za moment zaniku piany przyjęto chwilę pojawienia się na powierzchni emulsji pierwszego „oka”, czyli wolnego od piany lustra emulsji. Warunki badania:

- temperatura: $20 \pm 0,1^{\circ} \mathrm{C}$,

- objętość próbki: $145 \mathrm{ml}$,

- przepływ powietrza: $1000 \pm 25 \mathrm{ml} / \mathrm{min}$,

- czas przepływu powietrza: $5 \mathrm{~min}$.

Do badań wykorzystano stanowisko (fotografia 1) składające się z:

- cylindra pomiarowego o pojemności $600 \mathrm{ml} \mathrm{z}$ podziałką umożliwiającą odczyt z dokładnością do $5 \mathrm{ml}$,

- łaźni wodnej o pojemności około $5000 \mathrm{ml} \mathrm{z}$ termoregulatorem umożliwiającym utrzymanie temperatury z dokładnością do $1^{\circ} \mathrm{C}$,

- bełkotki napowietrzającej z porowatym kulistym spiekiem korundowym o średnicy 25,5 mm, maksymalnej średnicy porów $45 \mu \mathrm{m}$ i przepuszczalności powietrza przy ciśnieniu $250 \mathrm{mmH}_{2} \mathrm{O}$ wynoszącej $6400 \mathrm{ml} / \mathrm{min}$,

- termometru laboratoryjnego o zakresie pomiarowym $0 \div 40{ }^{\circ} \mathrm{C}$ umożliwiającego odczyt temperatury z dokładnością do $0,1^{\circ} \mathrm{C}$,

- rotametru pozwalającego na pomiar strumienia przepływającego powietrza z dokładnością do $25 \mathrm{ml} / \mathrm{min}$,

- źródła zasilania czystym i suchym powietrzem,

- płuczki szklanej wypełnionej watą, umieszczonej między źródłem zasilania powietrzem a rotametrem,
- sekundomierza umożliwiającego mierzenie czasu z dokładnością do $0,1 \mathrm{~s}$.

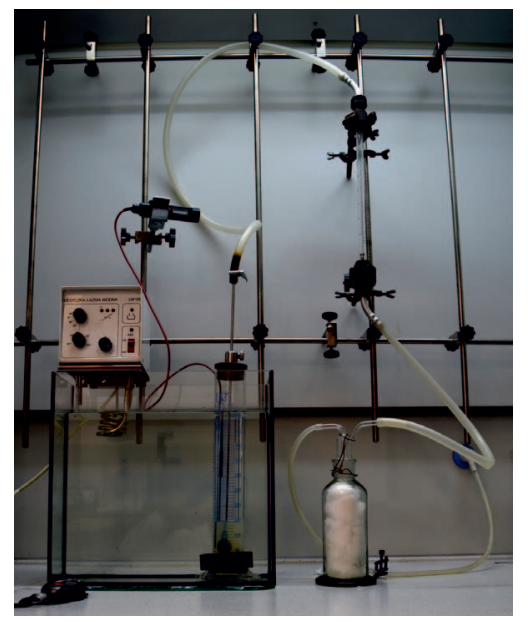

Fot. 1. Stanowisko badawcze do oznaczania skłonności do pienienia

(fot. INiG - PIB)

\section{Oznaczenie napięcia powierzchniowego}

Metoda oznaczania napięcia powierzchniowego na granicy faz ciecz-gaz polega na pomiarze siły, którą trzeba przyłożyć pionowo do pierścienia platynowego w celu oderwania go od tej powierzchni. Napięcie powierzchniowe przygotowanych próbek emulsji wobec powietrza zmierzono za pomocą tensjometru K8 firmy Petrotest (fotografia 2). Napięcie powierzchniowe wody destylowanej $\left(0^{\circ} \mathrm{n}\right)$ wyniosło $72,6 \mathrm{mN} / \mathrm{m}$, co pozwoliło uzyskać na tensjometrze wartość współczynnika korekcyjnego $k$ równą 1 .

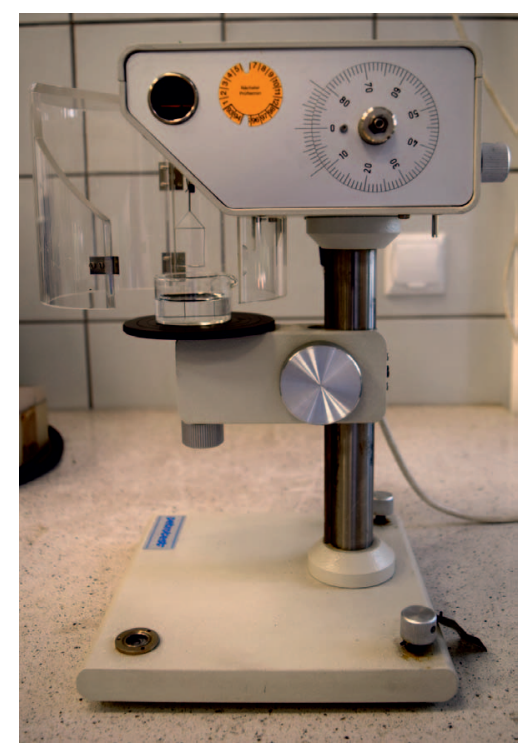

Fot. 2. Tensjometr K8

(fot. INiG - PIB) 


\section{Wyniki badań}

W tablicy 2 przedstawiono wyniki oznaczeń skłonności do pienienia, napięcia powierzchniowego oraz pH dla 5-proc. $(\mathrm{m} / \mathrm{m})$ emulsji sporządzonych z koncentratu 1 oraz dla koncentratu 1 wzbogaconego o dodatki przeciwpienne w minimalnych i maksymalnych stężeniach stosowania. Analogiczne wyniki dla koncentratu 2 przedstawiono w tablicy 3.

Wszystkie emulsje obu koncentratów sporządzone w wodzie o twardości $0^{\circ} \mathrm{n}$ wykazywały dużą skłonność do pienienia. Dla żadnej z nich nie udało się uzyskać wyników, ponieważ objętość powstającej piany przekraczała objętość cylindra pomiarowego - przyjęto, że w tych przypadkach ilość powstającej piany była większa niż $455 \mathrm{ml}$, ponieważ jest to maksymalna objętość piany, jaką można było zaobserwować w cylindrze o pojemności $600 \mathrm{ml}$.

Zaobserwowano znaczny wpływ twardości wody na skłonność do pienienia emulsji sporządzonych z obu koncentratów. Ze wzrostem twardości wody malała ilość powstającej piany oraz ulegał skróceniu czas zaniku piany. Ponadto dla każdej z próbek emulsji wraz ze wzrostem twardości wody malało napięcie powierzchniowe, a wzrastało $\mathrm{pH}$ emulsji.

W przypadku wszystkich emulsji sporządzonych z koncentratu 1 wzbogaconego o dodatki przeciwpienne, bez względu na twardość zastosowanej wody i rodzaj dodatku przeciwpiennego, wartości napięcia powierzchniowego i $\mathrm{pH}$ były niższe od analogicznych parametrów dla emulsji sporządzonych z koncentratu 1 bez dodatków przeciwpiennych. Ponadto wzrost stężenia wszystkich dodatków przeciwpiennych powodował obniżenie napięcia powierzchniowego i $\mathrm{pH}$ emulsji. Analogicznie rezultaty uzyskano w przypadku koncentratu 2 .

Dla obu koncentratów najskuteczniejszym spośród przebadanych dodatków przeciwpiennych okazał się dodatek P1 (na bazie trójwymiarowego siloksanu, w którym jako nośnik zastosowano polioksyalkilan) użyty w maksymalnym stężeniu $0,1 \%(\mathrm{~m} / \mathrm{m})$; zaobserwowano największe ograniczenie skłonności do pienienia wytworzonych emulsji - najmniej piany powstało, najszybciej zanikła.

Wszystkie emulsje (bez względu na twardość wody) sporządzone z obu koncentratów z dodatkiem P2 (na bazie trójwymiarowego siloksanu,

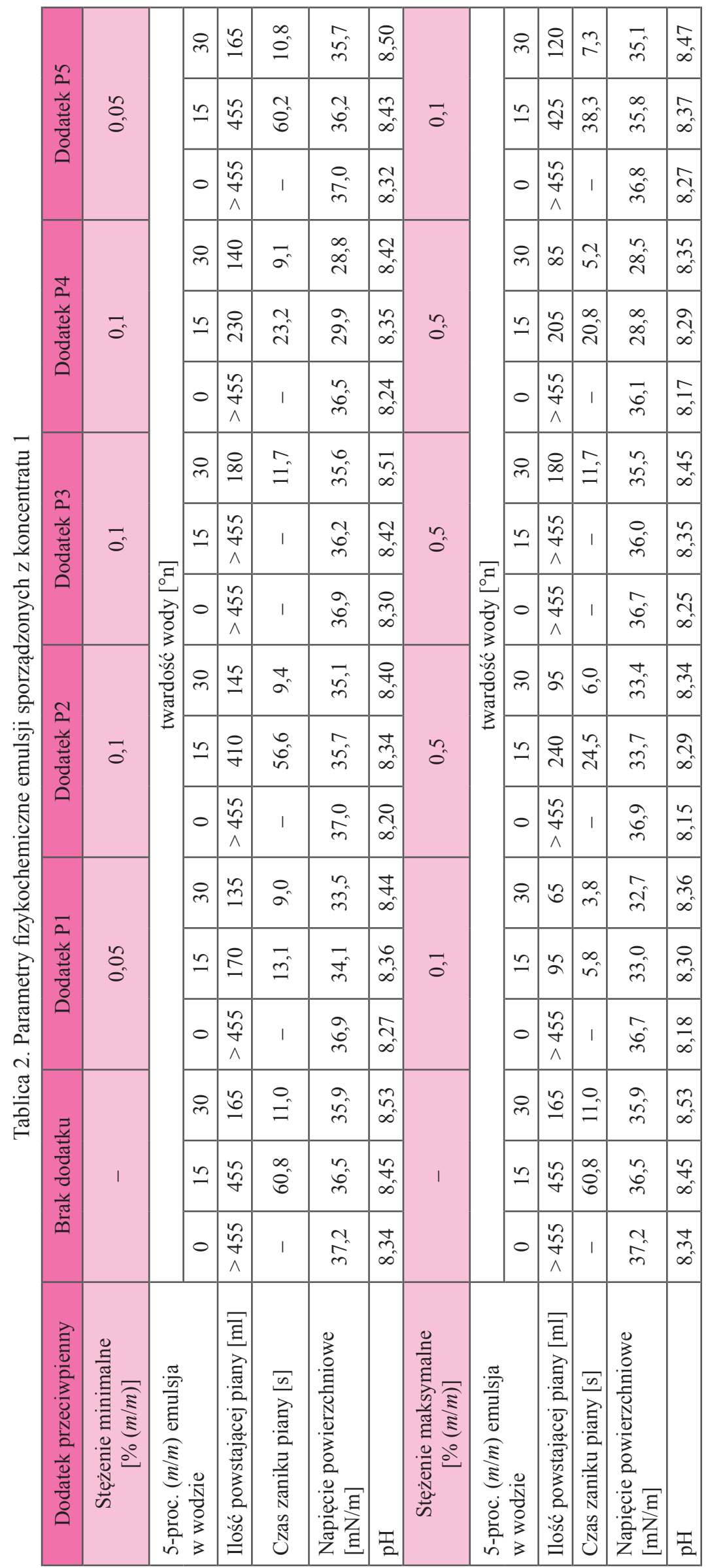

Nafta-Gaz, nr 4/2018 


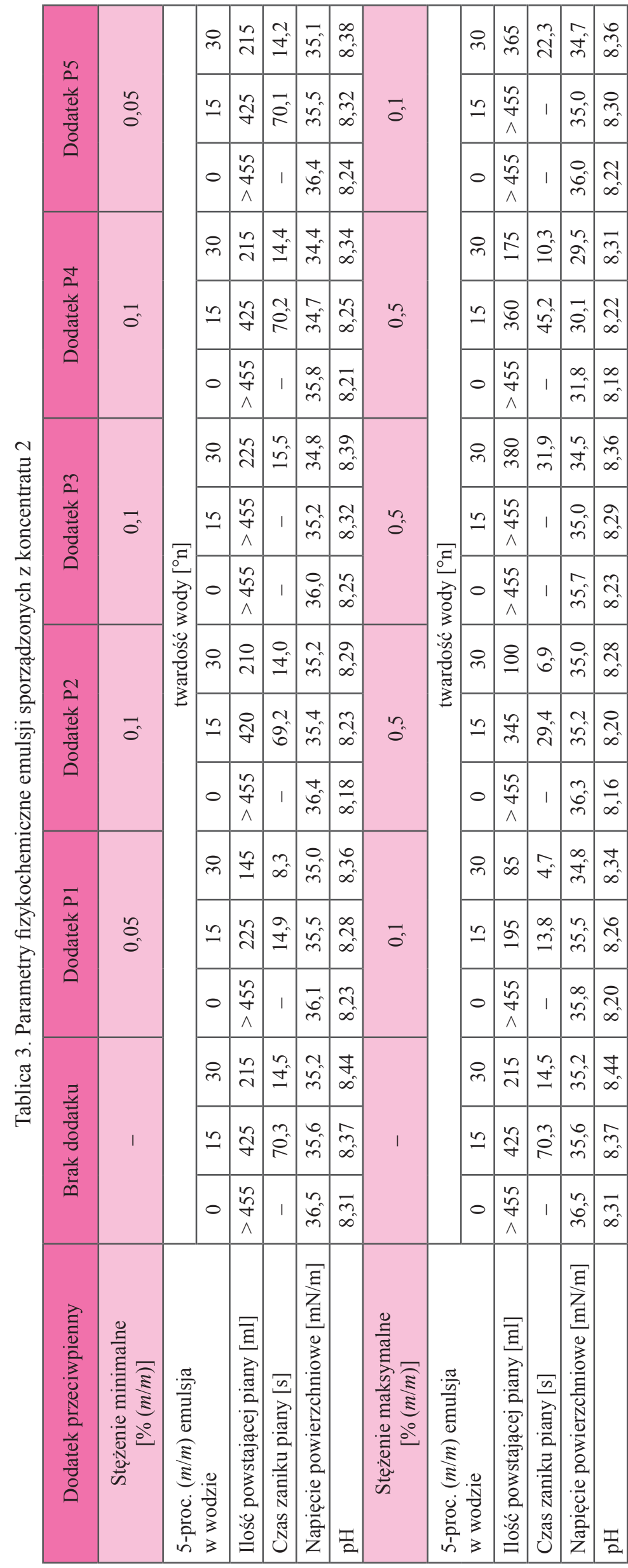

z wodą jako nośnikiem) wykazały najniższe wartości $\mathrm{pH}$ emulsji.

Dodatek P3 (z grupy dodatków przeciwpiennych clo$u d$ point antifoamers: block copolymers) nie sprawdził się jako środek ograniczający pienienie. Dla obu koncentratów pogarszał on skłonność emulsji do pienienia.

W przypadku obu koncentratów z dodatkiem $\mathrm{P} 4$ (na bazie polidimetylosiloksanu, z wodą jako nośnikiem) wszystkie sporządzone emulsje (bez względu na twardość wody) charakteryzowały się najniższymi wartościami napięcia powierzchniowego.

Zastosowanie w koncentracie 1 dodatku P5 dopiero w jego maksymalnym stężeniu pozwoliło na ograniczenie skłonności emulsji do pienienia. Natomiast użycie tego samego dodatku w jego maksymalnym stężeniu w koncentracie 2 zwiększyło skłonność do pienienia emulsji. Dodatek P5 jest dodatkiem na bazie polidimetylosiloksanu i cyklosiloksanów, w którym jako aktywator zastosowano krzemionkę, natomiast jako nośnik - wodę.

Dla 5-proc. $(\mathrm{m} / \mathrm{m})$ emulsji zarówno sporządzonych z koncentratu 1, jak i z koncentratu 2 zawierających badane dodatki przeciwpienne nie zaobserwowano zależności pomiędzy ograniczeniem skłonności pienienia emulsji przez te dodatki ( $\mathrm{tj}$. ilości powstającej piany i czasem jej zaniku) a napięciem powierzchniowym i pH.

\section{Podsumowanie}

Zastosowana w badaniach procedura oznaczania skłonności do pienienia emulsji cieczy wodorozcieńczalnych pozwoliła na porównywanie tej właściwości dla różnych cieczy wodorozcieńczalnych, a także użytych w ich koncentratach dodatków przeciwpiennych o różnych charakterach chemicznych.

W przypadku emulsji sporządzonych z obu koncentratów zaobserwowano znaczny wpływ twardości wody na ich skłonność do pienienia. Ze wzrostem twardości wody malała ilość powstającej piany oraz ulegał skróceniu czas jej zaniku. Ponadto dla każdej z próbek emulsji wraz ze wzrostem twardości wody malało napięcie powierzchniowe, a wzrastało $\mathrm{pH}$ emulsji.

Dla obu koncentratów najskuteczniejszym spośród przebadanych dodatków przeciwpiennych okazał się dodatek P1 (na bazie trójwymiarowego siloksanu, z polioksyalkilanem jako nośnikiem) zastosowany w maksymalnym zalecanym stężeniu $0,1 \%(\mathrm{~m} / \mathrm{m})$. Natomiast dodatek P3 (z grupy dodatków przeciwpiennych cloud point antifoamers: block copolymers) nie sprawdził się jako środek ograniczający pienienie. Charakter 
chemiczny dodatków przeciwpiennych oraz rodzaj struktury chemicznej związków silikonowych będących podstawowym składnikiem dodatków przeciwpiennych P1, P2, P4 i P5 miał istotny wpływ na skuteczność zmniejszania skłonności do pienienia badanych koncentratów cieczy wodorozcieńczalnych.

Prosimy cytować jako: Nafta-Gaz 2018, nr 4, s. 329-335, DOI: 10.18668/NG.2018.04.09

Artykuł nadesłano do Redakcji 24.11.2017 r. Zatwierdzono do druku 6.03.2018 r.

Artykuł powstał na podstawie pracy statutowej pt.: Badania ograniczenia pienienia cieczy wodorozcieńczalnych - praca INiG - PIB na zlecenie MNiSW; nr zlecenia: 0096/TO/17/01, nr archiwalny: DK-4100-83/17.

\section{Literatura}

[1] Bagwe R.: Phosponium Ionic Liquid as Defoamers: Structure - Property - Application Performance Correlation. $13^{\text {th }}$ IACIS International Conference on Surface and Colloid Science and the $83^{\text {rd }}$ ACS Colloid \& Surface Science Symposium, New York 14-19.06.2009.

[2] Denkov N.: Mechanism of Foam Destruction by Oil Based Antifoams. Langmuir 2004, vol. 20, nr 22, s. 9463-9505.

[3] Denkov N., Cooper P., Martin J.: Mechanism of Action of Mixed Solid-Liquid Antifoams. 1. Dynamics of Foam Film Rupture. Langmuir 1999, vol. 15, nr 24, s. 8514-8529.

[4] Denkov N.D., Marinova K.: Antifoam effects of solid particles, oil drops and oil-solid compounds in aqueous foams. Colloidal Particles at Liquid Interfaces, vol. 10, Cambridge University Press 2006, s. 383-444.

[5] Denkov N.D., Marinova K., Tcholakova S.: Mechanistic understanding of the modes of action of foam control agents. Advances in Colloid and Interface Science 2014, vol. 206, s. 57-67.

[6] Derjaguin B., Landau L.: Theory of the stability of strongly charged lyophobic sols and of the adhesion of strongly charged particles in solutions of electrolytes. Acta Physico Chemica U.R.S.S. 1941, vol. 14, s. 633-662.

[7] Dwuletzki H.: Schwerent Flammbare Hydraulikmedien von Typ HFA. II Międzynarodowa Konferencja: Teoretyczne i praktyczne aspekty stosowania środków smarowych, Ustroń 29-31.05.2006.

[8] Garrett P.R.: Defoaming: Antifoams and Mechanical Methods. Current Opinion in Colloid \& Interface Science 2015, vol. 20, nr 2, s. 81-91.

[9] Hilberer A., Chao S.-H.: Antifoaming agents. Encyclopedia of Polymer Science and Technology, Wiley and Sons Press 2012.

[10] Hill H., Eastoe J.: Foams: From nature to industry. Advances in Colloid and Interface Science 2017, vol. 247, s. 496-513.

[11] Karakashev S.I., Grozdanova M.V.: Foams and antifoams. Advances in Colloid and Interface Science 2012, vol. 176-177, s. $1-17$.

[12] Marinova K.G., Dimitrova L.M., Marinov R.Y., Denkov N.D., Kingma A.: Impact of the surfactant structure on the foaming/ defoaming performance of nonionic block copolymers in $\mathrm{Na}$ caseinate solutions. Bulgarian Journal of Physics 2012, vol. 39, nr 1, s. 53-64.

[13] Owen M.J.: Defoamers. [W:] Kirk-Othmer (ed.), Encyclopedia of Chemical Technology. Wiley and Sons Press, New Jersey 2000.

[14] Pugh R.J.: Bubble and Foam Chemistry. Cambridge University Press 2016, s. 1-48.

[15] Pugh R.J.: Foam Breaking in Aqueous Systems. [W:] Holmberg E.K. (ed.): Handbook of Applied Surface and Colloid Chemistry. Wiley and Sons Press, New Jersey 2001.

[16] Rembiesa-Śmiszek A.: Trudnopalne ciecze hydrauliczne HFC i HFC-E zawierajace polialkilenoglikole. Nafta-Gaz 2013, nr 3, s. 235-240.

[17] Rutkowska M., Skibińska A.: Opracowanie nowej generacji płynów do obróbki metali oraz kompleksowej technologii ich wytwarzania opartej na bazach olejowych, pochodzacych z recyklingu olejów odpadowych. Sprawozdanie z projektu INNOTECH-K1/N1/62/149772/NCBR/12, Kraków, wrzesień 2012.

[18] Steinmec F.: Krajowe wodorozcieńczalne środki chłodzacosmarujace do obróbki metali skrawaniem. Nafta 1990, vol. 46, nr 1-3, s. 37-41.

[19] Steinmec F., Bednarska A., Łapa M.: Rozwój krajowych mikroemulsyjnych cieczy hydraulicznych HFAE. Nafta-Gaz 2009, nr 1, s. 37-43.

[20] Stocco A., Rio E., Binks B.P., Langevin D.: Aqueous foams stabilized solely by particles. Soft Matter 2011, vol. 7, no. 4, s. 1260.

[21] Strona internetowa: http://naftochem.pl/srodki-do-obrobki-skrawaniem/ (dostęp: 28.07.2017).

\section{Normy prawne i normatywne}

[22] PN-C-04809:1990 Środki powierzchniowo czynne. Oznaczanie napięcia powierzchniowego i napięcia międzyfazowego.

[23] PN-C-04963:1989 Analiza chemiczna-Oznaczanie pH wodnych roztworów produktów chemicznych.

[24] PN-M-55789:1992 Badania działania korodujacego cieczy technologicznych na stopy żelaza.

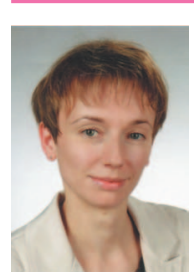

Mgr inż. Agnieszka SKIBIŃSKA

Asystent w Zakładzie Olejów, Środków Smarowych i Asfaltów.

Instytut Nafty i Gazu - Państwowy Instytut Badawczy ul. Lubicz $25 \mathrm{~A}$

31-503 Kraków

E-mail:agnieszka.skibinska@inig.pl 